\title{
PREGNANCY-SPECIFIC PROTEIN B IN YANKASA EWES DURING PREGNANCY AND POSTPARTUM PERIODS
}

Adewale Ayodeji Adeyeye ${ }^{1}$, Yushàu Usman Abubakar², Olufisayo Oluwadamilare Leigh ${ }^{3}$, Iyorhembe Utim Ate ${ }^{4,8}$, Jashilagari Stephen ${ }^{5}$, Kabir Ayo Raheem ${ }^{6}$, Simon Azubuike Ubah ${ }^{7}$

${ }^{1}$ Department of Theriogenology and Animal Production, Faculty of Veterinary Medicine, Usmanu Danfodiyo University, Sokoto, Nigeria

${ }^{2}$ National Animal Production Research Institute, Ahmadu Bello University, Zaria, Nigeria ${ }^{3}$ Department of Theriogenology, Faculty of Veterinary Medicine,

University of Ibadan, Ibadan, Nigeria

${ }^{4}$ Department of Theriogenology and Production, Faculty of Veterinary Medicine, Ahmadu Bello University, Zaria, Nigeria

${ }^{5}$ Department of Theriogenology, Faculty of Veterinary Medicine,

University of Maiduguri, Nigeria

${ }^{6}$ Department of Theriogenology, College of Veterinary Medicine,

Michael Okpara University of Agriculture, Umudike, Nigeria

${ }^{7}$ Department of Theriogenology, Faculty of Veterinary Medicine, University of Abuja, Nigeria

${ }^{8}$ Department of Theriogenology, College of Veterinary Medicine, University of Agriculture, Makurdi, Nigeria

Received 20 August 2020; Received in revised form 2 December 2020; Accepted 7 December 2020

\begin{abstract}
Pregnancy-specific protein B (PSPB) is produced by mono and binucleate trophoblast cells in the placenta of ruminants during pregnancy. This study was designed to determine the pattern of serum PSPB in Yankasa ewes during pregnancy and postpartum periods. Mature cycling Yankasa ewes were synchronized and divided into two groups A $(n=11)$ and $B(n=13)$. Group A was bred, while group B was unbred. Blood samples for PSPB assessment were collected from the ewes starting from the day of breeding until 4 weeks post-lambing. All pregnant Yankasa ewes lambed with singleton lambs after an average of 151.18 days. There was a significant $(p<0.05)$ increase in PSPB in pregnant compared with the non-pregnant ewes in the period between 3 weeks post-breeding and 3 weeks post-lambing. Peaks were detected in the first $(100.60 \mathrm{ng} / \mathrm{ml})$, second $(133.90 \mathrm{ng} / \mathrm{ml})$, and third $(114.82 \mathrm{ng} / \mathrm{ml})$ trimesters at 5, 10 and 21 weeks of gestation, respectively, but steadily decreased within 4 weeks $(2.38 \mathrm{ng} / \mathrm{ml})$ postpartum. In conclusion, PSPB detected pregnancy in Yankasa ewes from 3 weeks post-breeding with peak levels at 5,10 and 21 weeks post-breeding in the first, second, and third trimesters, respectively. PSPB decreased gradually after lambing until 4 weeks postpartum.
\end{abstract}

Key words: pregnancy specific protein-B, pregnancy, postpartum, Yankasa ewes

\section{INTRODUCTION}

Sheep are estimated to make up $27 \%$ (37.4 million) of Nigeria`s livestock population (1), where they

Corresponding author: Dr. Adewale Ayodeji Adeyeye, $\mathrm{PhD}$

E-mail address: adewale.adeyeye@udusok.edu.ng

Present address: Department of Theriogenology and Animal Production, Faculty of Veterinary Medicine, Usmanu Danfodiyo University, Sokoto, Nigeria Phone: +2348032859940

Copyright: (C) 2021 Adeyeye A.A. This is an open-access article published under the terms of the Creative Commons Attribution License which permits unrestricted use, distribution, and reproduction in any medium, provided the original author and source are credited. Competing Interests: The authors have declared that no competing interests exist.

Available Online First: 22 January 2021

Published on: 15 March 2021

https://doi.org/10.2478/macvetrev-2021-0010 are kept for meat and milk production (2). They also play a socio-economic role in Nigerians's life, particularly in the northern part where they are kept and used during festive periods such as Eld-el Kabir, wedding, and naming ceremonies (3). Sheep are part of almost all farming systems in Nigeria, where they are associated with mixed farming and pastoralism (4). They are essential in sustaining low-income families, mainly in the rural areas of Nigeria (5). Generally, four breeds of sheep are 
indigenous to Nigeria, namely Balami, Uda, West African dwarf (WAD) and Yankasa. However, Yankasa sheep is the most abundant breed in Nigeria (2), females attaining puberty at $238 \pm 23.4$ days at an average weight of $18.4 \pm 0.4 \mathrm{~kg}(6)$. Adult Yankasa ewes weigh $21.48 \pm 0.48 \mathrm{~kg}$, and produce lambs in a singleton to twin ratio of $1: 2.8$ (7). Pregnancy is the period beginning immediately after fertilization from a fertile mating till parturition (8) and takes about 147-152 days in sheep (9). It is an integral part of animal reproduction, characterized by embryo formation and fetal development due to changes in the physiology of the reproductive tract $(8,9)$. During this period, several biomarkers, such as enzymes, growth factors, inhibitors, and hormones are released into the circulation (10). Pregnancy specific-protein B (PSPB) is produced during pregnancy in sheep and can be considered as its marker (11).

PSPB is also known as pregnancy-associated glycoprotein (PAG), pregnancy-serum protein $60 \mathrm{kDa}$, and SBU-3 antigen (10). They constitute a large family of placenta glycoproteins, belonging to a group of proteolytic enzymes known as aspartic proteinases (12). These proteins are produced by mono and binucleate trophoblast cells in the ruminant placenta and then released into the maternal circulation. Its levels in plasma and milk are used for pregnancy diagnosis (13), fetal number assessment (14), pregnancy wastage (15, 16), pregnancy loss (14), and obstetric diseases (17). The concentration of PSPB is influenced by animal species, breed, parity, and sex of the fetus $(18,19)$. The pattern of PSPB during pregnancy and postpartum periods has been described in some breeds of sheep, such as Churra, Merino (18) and Assaf (20). They have also been described in Boer (21), Moxoto and Canine goats (22), as well as in buffalo cows (23). However, the pattern of PSPB during pregnancy and postpartum periods in Yankasa ewes has not been described to the best of our knowledge. Information on the profile of PSPB in pregnancy will assist in planning feeding strategies to avoid metabolic diseases related to pregnancy, such as pregnancy toxemia and birth of viable and healthy offsprings. In addition, it will contribute to the existing knowledge on the use of PSPB in pregnancy diagnosis and monitoring improving animal productivity and reproductive performance.

\section{MATERIAL AND METHODS}

\section{Experimental site}

The study was carried out at the animal house of the Faculty of Veterinary Medicine and Reproduction Laboratory of National Animal Production Research Institute (NAPRI), Ahmadu Bello University, Zaria, Nigeria. Zaria is within the Guinea Savannah zone of Nigeria, between $11^{0}$ and $12^{0}$ North and between $7^{0}$ and $8^{0}$ East at $650 \mathrm{~m}$ above sea level.

\section{Experimental animals}

Thirty cycling Yankasa ewes aged between 1.5 and 2.5 years, with an average weight of $19 \pm 1.14 \mathrm{~kg}$ were used for this study. The animals were acquired from the small ruminant flock of NAPRI and local markets around Zaria, Nigeria. They were acclimatized for 6 weeks and screened for common parasites during this period. The animals were fed on hay and concentrate supplements in the morning and evening, whereas water and salt-blocks were given ad libitum. Ethical approval for this study was obtained from the Ahmadu Bello University Committee on Animal Use and Care, with approval number ABUCAUC/02/2013/001.

\section{Experimental design}

Following acclimatization, estrus synchronization was achieved using $5 \mathrm{mg}$ of Lutalyse $\AA$ (Dinoprost tromethamine). Twenty-six ewes showed signs of estrus. Thirteen out of the twenty-six ewes were bred with rams of good fecundity (sperm volume $0.72 \mathrm{ml}$, sperm concentration $300 \times 10^{6}$; percentage of live sperm $97.65 \%$; sperm abnormalities - 20\%), while the remaining ewes were unbred. Pregnancy was determined by non-return to estrus and persistent high blood levels of progesterone $\left(\mathrm{P}_{4}\right)$ 18-24 days post-breeding. The bred and unbred ewes were tagged and grouped as A and B, respectively. On day 45 post-breeding, two ewes in group A were diagnosed non-pregnant by ultrasonography (Medison SA600V, Germany) and subsequently excluded from the study. Blood samples were collected on a weekly basis $(7 \pm 1$ day) in the period between the onset of breeding and four weeks post lambing in ewes of both groups.

\section{Blood collection and analysis}

About $5 \mathrm{ml}$ of blood was collected weekly from the jugular vein of each ewe into plain test tubes and centrifuged at 9,000 $\mathrm{g}$ for $5 \mathrm{mins}$. Blood serum was harvested and stored at $-20{ }^{\circ} \mathrm{C}$ until analysis. 
Assay for pregnancy-specific protein B

Enzyme-linked immunosorbent assay was carried out on the serum samples using bioPRYN quantitative PSPB ELISA kits (Biotracking LLC; Moscow ID) to determine the concentrations of PSPB in the test samples. The manufacturer's instructions were followed, as previously described by Adeyeye et al. (17). Values of obtained optical density were added into an Excel package pre-programmed by the manufacturers, from where actual PSPB values were obtained. The test kit had a sensitivity of $99.9 \%$ and a specificity range of $90-99 \%$.

\section{Data analysis}

Data of PSPB values were analyzed using $t$-test of GraphPad (2000) and presented as mean \pm error of mean in graphs. Values of $p<0.05$ were considered statistically significant.

\section{RESULTS}

All ewes in group A lambed singleton lambs after a mean \pm standard error gestation length of $151.18 \pm 0.58$ days. The profile of PSPB during pregnancy is presented in Fig. 1. The mean weekly profile of PSPB ranged from 0.27 to $133.90 \mathrm{ng} / \mathrm{ml}$ and 0.10 to $0.97 \mathrm{ng} / \mathrm{ml}$ in pregnant and non-pregnant ewes, respectively. There was no significant $(p>0.05)$ difference in serum PSPB levels between pregnant and non-pregnant ewes from the time of first standing heat to the second-week post-breeding. However, serum PSPB significantly $(p<0.05)$ increased in pregnant ewes compared to non-pregnant ewes in the period between the third-week and the time of parturition. In the first trimester, PSPB levels peaked at the fifth-week post-breeding with a mean of $100.60 \mathrm{ng} / \mathrm{ml}$, while the peak in the second trimester occurred at the tenth-week post-breeding with a mean of $133.90 \mathrm{ng} / \mathrm{ml}$. There was a gradual increase in PSPB levels in the third trimester reaching the peak a few days before the parturition.

The serum PSPB levels of postpartum ewes are presented in Fig. 2. The mean PSPB levels post-breeding ranged from $2.38 \mathrm{ng} / \mathrm{ml}$ at the fourth-week to $114.82 \mathrm{ng} / \mathrm{ml}$ at parturition. There was a gradual and statistically significant $(p<0.05)$ decrease in PSPB between postpartum and nonpregnant ewes from lambing until the third week postpartum. The serum levels of postpartum ewes were not statistically significant $(p>0.05)$ at the fourth-week postpartum when compared with non-pregnant ewes.

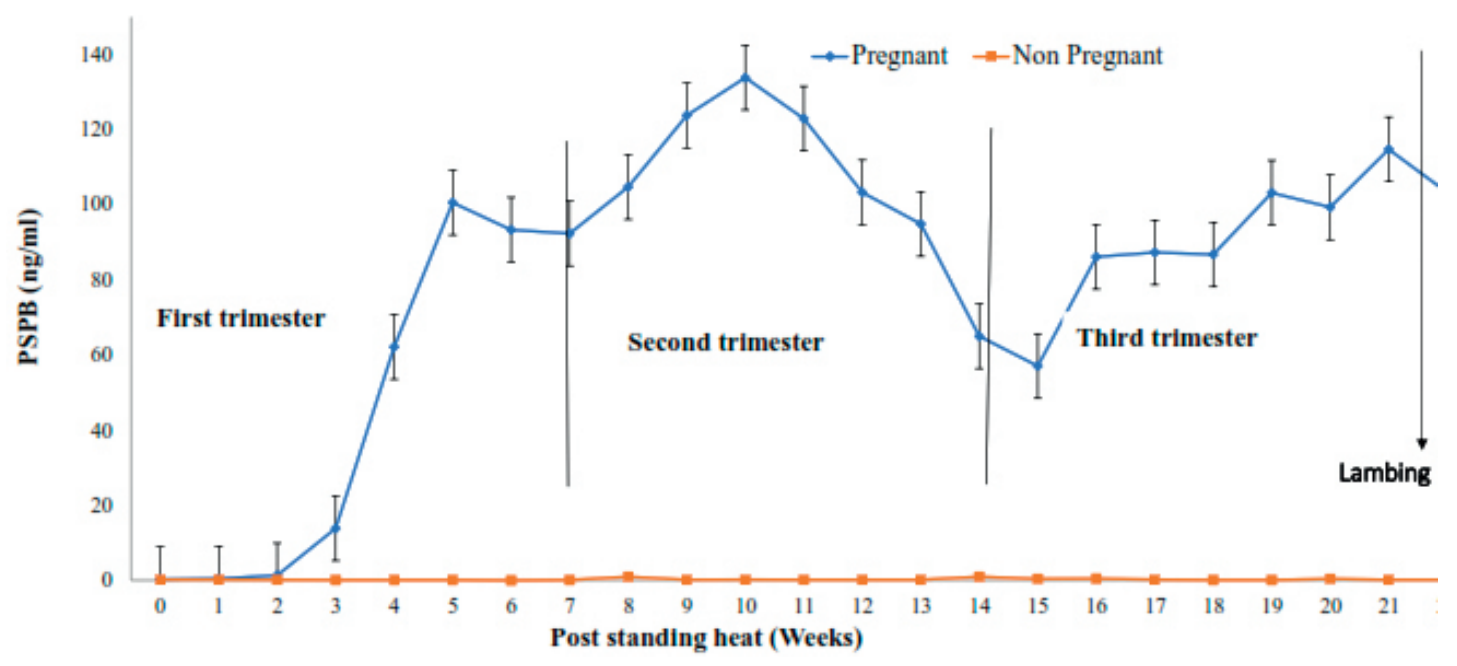

Figure 1. Pattern of pregnancy-specific protein B (PSPB) during pregnancy in Yankasa sheep Mean \pm SEM gestation length of pregnant ewes - $151.18 \pm 0.58$

*Statistically significant $(\mathrm{p}<0.05)$ from week 3 until lambing 


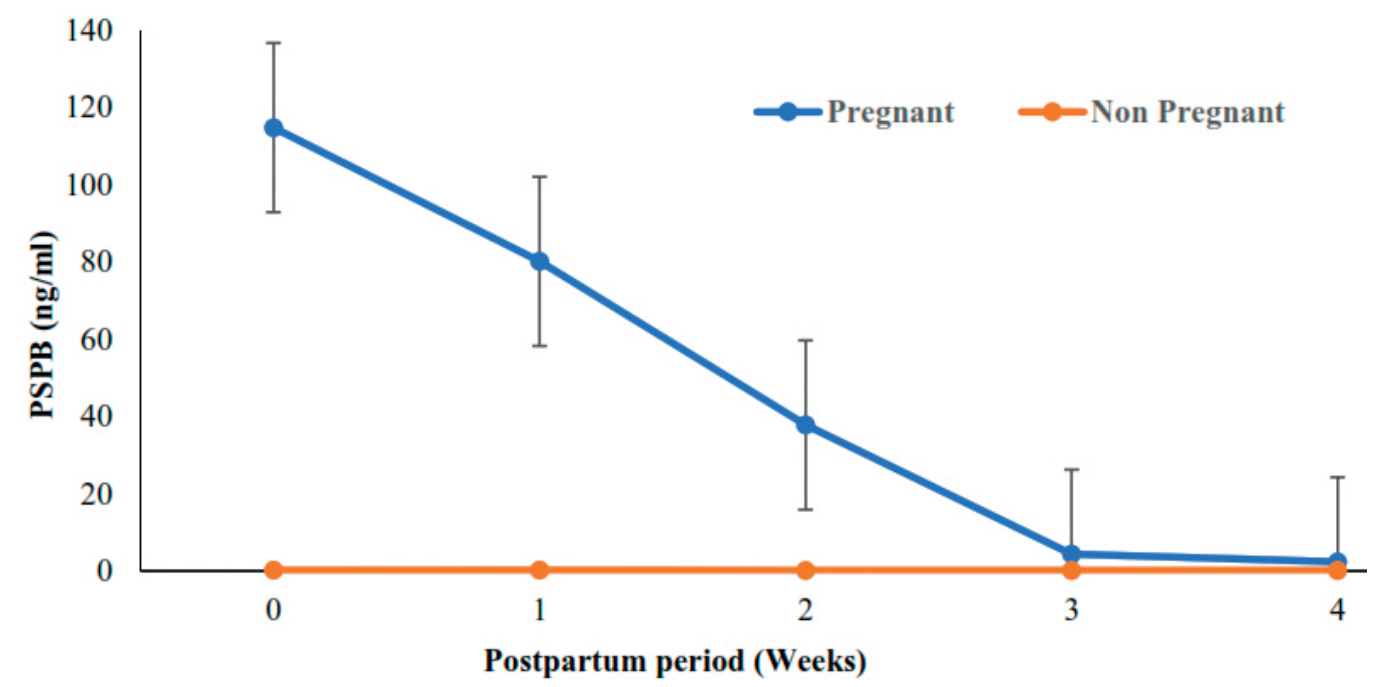

Figure 2. Pattern of pregnancy-specific protein B (PSPB) during postpartum period in Yankasa sheep *Statistically significant $(p<0.05)$ from lambing until week 3 postpartum

\section{DISCUSSION}

PSPB is a biomarker synthesized in the superficial layer of the developing trophoblast of ruminants and released into the maternal circulation (10). Its concentrations are detected and used to investigate placental function during pregnancy (11). The present study describes the pattern of PSPB during pregnancy and postpartum periods in Yankasa sheep for the first time, which is the most abundant breed of sheep in Nigeria (2). There were no multiple births among the Yankasa ewes used in this study. PSPB increases in ewes with multiple births (13) as a result of the increase in the total weight of placentomes that rises with the fetal number (24).

In our study, the levels of PSPB in pregnant ewes were not significantly different from those in non-pregnant ewes within two weeks of breeding. However, it increased substantially between weeks 2 and 3 (days 14 and 21) post-breeding. This finding is similar to previous reports in other breeds such as Merino (18), Suffolk, Panama (25), Blackheaded German Mutton, Rhoen and Dopper ewes (26). It is also similar to previous reports in goats $(20,27)$ and buffaloes (23). Substantial PSPB levels between weeks 2 and 3 may suggest an early differentiation of binucleated cells in the trophoblast, movement from the placenta to the maternal endometrium and subsequent implantation in Yankasa ewes. The flow of binucleated cells to the endometrium is associated with the appearance of PSPB in maternal circulation during pregnancy $(18,25,28)$. The studies of El-Amiri et al. (28) further showed that PSPB is specifically detectable by day 18 of gestation in pregnant ewes but is low or undetectable in the non-pregnant ewes. This hypothesis needs to be evaluated in Yankasa ewes and other Nigerian breeds of sheep to determine the exact period between days 14 and 21 when PSPB can be used for pregnancy diagnosis. Early pregnancy diagnosis in sheep is crucial because it assists farmers in separating non-pregnant ewes for rebreeding.

The PSPB profile of pregnant Yankasa ewes in this study steadily increased with an uncomparable difference with the non-pregnant ewes from week 3 , reaching the first peak at week 5 . This finding is similar to earlier reports of Ranilla et al. (18) in Merino ewes, Willard et al. (25) in Suffolk and Panama ewes, as well as the report of LedezmaTorres et al. (26) in Blackhead German Mutton and Rhoen ewes. It is also similar to the report of Batalha et al. (22) in Alpine goats but varies with the report of Ranilla et al. (18) in Churra ewes. This may be associated with increased binucleated cell production following early differentiation. The highest peak in the first trimester was at week 5, similar to the pattern in Merino ewes but dissimilar to those in Churra ewes (18). This could be associated with variation in the genetic make-up of the breeds. Previous studies suggest a difference in PSPB levels among different breeds (22). Roberts et al. 
(19), therefore, recommended PSPB standards to be determined for every ovine breed. There was a slight decrease in PSPB of pregnant Yankasa ewes from week 5 to 7 post-breeding, and this varied with previous reports in Churra ewes (18) and Alpine goat (22). However, it is similar to the report of Ranilla et al. (18) in Merino ewes. The decline may be associated with the period of genes switching on and off. PSPB is a group of related proteins whose expression varies during pregnancy.

The PSPB of pregnant Yankasa ewes displayed a progressive increase from week 7 , attaining the highest peak of the second trimester at week ten post-breeding. Progressive increase similar to this has been reported in Blackheaded German Mutton, Rhoen, Dopper (26), Churra and Merino ewes (18). However, their peaks were at week 9 post-breeding, probably due to breed variations. The second trimester peak of PSPB at week 10 was the highest during pregnancy in our study. This has also been reported in Corriedale and Ile de France cross ewes (29), Boer goats (21) and Indian native goats (13), although their peaks were at day 95 (week 13-14), day 60 (week 8-9), and day 51 (week 7-8) post-breeding, respectively. The high level of PSPB during the second trimester may be associated with the numerous placenta proteins produced during this period. El Amiri et al. (30) and El Amiri et al. (31) had previously isolated several proteins between days 60 and 100 post-breeding in sheep. Several placenta proteins are also produced during the second trimester in cattle (32), and there is evidence of structural and immunological similarity between PSPB in sheep and cattle (33). It is also possible that the rapid placenta growth for the developing fetus occuring at this stage may account for the peak level.

There was a gradual decline in PSPB from week 10 to 15 of gestation in pregnant Yankasa ewes similar to the report of Rovani et al. (29) in Corriedale and Ile de France cross ewes. It is also similar to the reports of Ledezma-Torres et al. (26) in Blackheaded German Mutton, Rhoen and Dopper ewes, and the report of Batalha et al. (22) in Alpine goats and Shahin et al. (21) in Boer goats. However, there was variation in the pattern in Churra and Merino ewes (18), and Assaf sheep (20). These variations may be ascribed to differences in PSPB cross-reactivity in various breeds. Wallace et al. (34) had attributed the variation in PSPB pattern to cross-reactivity between species and breeds. In the present study, the PSPB of pregnant Yankasa ewes gradually increased from week 15 post-breeding to the parturition (week 21.5), although there were fluctuations at weeks 18 and 20. This is similar to previous reports in sheep $(18,20)$ but differs from the reports in goats $(21$, 22). An increase in PSPB before parturition has also been reported in cattle (27) and buffalo (23). The differences may be species-specific, probably due to larger placenta mass and blood distribution through the compartments in ewe and cow. Sousa et al. (10) highlighted these differences as possible factors that could influence PSPB concentration.

During the postpartum period, there was a steady decrease in the PSPB profile of Yankasa ewes starting from the parturition until the fourth-week post-lambing. However, PSPB was significantly different between pregnant and non-pregnant ewes up to three weeks postpartum. This is consistent with previous reports in Suffolk and Panama ewes (25), Corriedale and Ile de France cross ewes (29) and Boer goats (21). However, there were variations with earlier reports in Churra, Merino (18), Assaf ewes (20) and Alpine goats (22) where detectable levels were present until four weeks postpartum. In this study, basal levels, though insignificant, were also present until the fourth week postpartum. This finding supports earlier studies that reported a faster declining rate (by 28 days) in ewes compared to cows (by 100 days) (10). The shorter half-life in sheep (4.5 days) might explain this finding (35). The practical implication of determining PSPB levels in the postpartum period in bred Yankasa ewes would be decreasing of the false-positive results in pregnancy diagnosis.

\section{CONCLUSION}

The study showed that serum PSPB concentrations increased in pregnant ewes from week 3 post-breeding. It also showed that peak levels of PSPB in pregnant Yankasa sheep occurs at week 5, 10, and 21 post-breeding in the first, second, and third trimesters, respectively. PSPB decreased gradually after lambing until fourthweek postpartum.

\section{CONFLICT OF INTEREST}

The authors declared that they have no potential conflict of interest with respect to the authorship and/or publication of this article.

\section{ACKNOWLEDGEMENTS}

The authors appreciate Prof. Jerome Jefu former Executive Director and Prof. P.I. Rekwot former 
Assistant Director (Research) both of the National Animal Production Research Institute (NAPRI), ABU, Zaria, Nigeria for providing some of the animals used for this study. The support we received from Dr. Josh Branen of Biotracking Inc. Moscow, USA is also appreciated. We thank Mr. S. I. B. Bolaji of the Reproduction Laboratory, NAPRI-ABU, Zaria, Nigeria for his technical assistance.

\section{AUTHORS' CONTRIBUTIONS}

AAA made the conceptualization, designed the methodology and wrote the original draft. YUA designed the methodology and was responsible for the resources. OOL was involved in the methodology design, resources and manuscript editing. IUA did the conceptualization, supervision and manuscript editing. JS was responsible for methodology design, manuscript writing and editing. KAR performed the data analysis and manuscript writing and editing. SAU was responsible for resources and manuscript editing.

\section{REFERENCES}

1. NASS (2011). National agricultural sample survey on animal census. National bureau of statistics, Abuja, Nigeria

http://nigeria.countrystat.org/documents/detail/ en/c/454834/

2. Blench, R. (1999). Traditional livestock breeds: geographical distribution and dynamics in relation to the ecology of West Africa. ODI Working paper. 122.

3. Umaru, M.A., Adeyeye, A.A., Abubakar, A., Garba, H.S. (2009). Retrospective analysis of disease conditions among reproductive domestic ruminants in Sokoto, Nigeria. Anim Res Int. 6(1): 946-948. https://doi.org/10.4314/ari.v6i1.48100

4. David-West, K.B. (1985). Role of government in small ruminant production. Proceedings of the national conference on small ruminants production. NAPRI, October, 6-10, (pp. 10-16), Shika, ABU, Zaria.

5. Yakubu, A., Raji, A.O., Omeje, J.N. (2010). Genetic and phenotypic differentiation of qualitative traits in Nigerian indigenous goat and sheep populations. J Agric Biol Sci. 5(2): 58-66.

6. Oyedipe, E.O., Pathiraja, N., Edqvist, L.E., Buvanendran, V. (1986). Onset of puberty and estrous cycle phenomena in Yankasa ewes as monitored by plasma progesterone concentrations. Anim Reprod Sci. 12(3): 195-199. https://doi.org/10.1016/0378-4320(86)90040-0
7. Afolayan, R.A., Adeyinka, I.A., Lakpini, C.A.M. (2006). The estimation of live weight from body measurements in Yankasa sheep. Czech J Anim Sci. 51(8): 343. https://doi.org/10.17221/3948-CJAS

8. Jainudeen, M.R., Hafez, E.S. (2000). Gestation, prenatal physiology, and parturition. In: B.Hafez, E.S.E Hafez (Eds.), Reproduction in farm animals, 7th Edition. (pp. 140-155). Wiley-Blackwell. https://oi.org/10.1002/9781119265306.ch10

9. Noakes, D.E., Parkinson, T.J, England, G.C. (2001). Arthur's veterinary reproduction and obstetrics. W.B. Saunders Ltd.

10. Sousa, N.M., Beckers, J.F, Gajewski, Z. (2008). Current trends in follow-up of trophoblastic function in ruminant species. J Physiol Pharmacol. 59(Suppl. 9): 65-74.

11. Sousa, N.M., Ayad, A., Beckers, J.F, Gajewski, Z. (2006). Pregnancy-associated glycoproteins (PAG) as pregnancy markers in the ruminants. J Physiol Pharmacol. 57(Suppl. 8): 153-171.

12. Xie, S., Low, B.G., Nagel, R.J., Beckers, J.F., Michael Roberts, R. (1994). A novel glycoprotein of the aspartic proteinase gene family expressed in bovine placental trophectoderm. Biol Reprod. 51(6): 1145-1153.

https://doi.org/10.1095/biolreprod51.6.1145

PMid:7534122

13. Singh, S.P., Natesan, R., Sharma, N., Goel, A.K., Singh, M.K., Kharche, S.D. (2019). Pregnancyassociated glycoprotein profile in milk and its relationship with the circulating level during early pregnancy in goats. Small Rumin Res. 173, 81-87. https://doi.org/10.1016/j.smallrumres.2019.02.017

14. Hussein, M.S., Bedier, W.E., Deghedy, A., El-Desouky, A.M., Ramoun, A.A. (2017). Serum concentration of pregnancy-associated glycoproteins (PAGs) as a predictor for embryonic/ fetal losses and fetal numbers in cross-bred ewes. Life Sci J. 14(5): 106-111.

15. Abubakar, M.I., Ahmed, A., Adeyeye, A.A., Baraya, Y.S. (2019). Comparative diagnosis of pregnancy wastage in cows at slaughter using pregnancy specific protein-B and post slaughter inspection diagnostic procedures. Anim Reprod Sci. 211: 106233. https://doi.org/10.1016/j.anireprosci.2019.106233 PMid:31785622

16. Adeyeye, A.A., Abubakar, M.I., Ahmed, A.G. (2019). Comparative detection of pregnancy in ewes at slaughter using pregnancy specific protein-B and post slaughter examination. Glob Vet. 21(2): 48-52. 
17. Adeyeye, A.A., Ate, I.U., Lawal, A.I., Adamu, S. (2016). Changes in some pregnancy biomarkers of Yankasa ewes experimentally infected with Trypanosoma evansi. Anim Reprod Sci. 167, 109-116. https://doi.org/10.1016/j.anireprosci.2016.02.014 PMid:26936656

18. Ranilla, M.J., Sulon, J., Carro, M.D., Mantecon, A.R., Beckers, J.F. (1994). Plasmatic profiles of pregnancy-associated glycoprotein and progesterone levels during gestation in Churra and Merino sheep. Theriogenology. 42(3): 537-545.

https://doi.org/10.1016/0093-691X(94)90691-B

19. Roberts, J.N., May, K.J., Veiga-Lopez, A. (2017). Time-dependent changes in pregnancy-associated glycoproteins and progesterone in commercial crossbred sheep. Theriogenology 89, 271-279. https://doi.org/10.1016/j.theriogenology.2016.10.029 PMid:28043363

20. Ranilla, M.J., Sulon, J., Mantecon, A.R., Beckers, J.F., Carro, M.D. (1997). Plasma pregnancy-associated glycoprotein and progesterone concentrations in pregnant Assaf ewes carrying single and twin lambs. Small Rumin Res. 24(2): 125-131. https://doi.org/10.1016/S0921-4488(96)00922-4

21. Shahin, M., Friedrich, M., Gauly, M., Beckers, J.F., Holtz, W. (2013). Pregnancy-associated glycoprotein (PAG) pattern and pregnancy detection in Boer goats using an ELISA with different antisera. Small Rumin Res. 113(1): 141-144.

https://doi.org/10.1016/j.smallrumres.2013.01.016

22. Sousa, N.M., Garbayo, J.M., Figueiredo, J.R., Sulon, J., Gonçalves, P.B., Beckers, J.F. (1999). Pregnancyassociated glycoprotein and progesterone profiles during pregnancy and postpartum in native goats from the north-east of Brazil. Small Rumin Res. 32(2): 137-147.

https://doi.org/10.1016/S0921-4488(98)00171-0

23. Barbato, O., Menchetti, L., Sousa, N.M., Malfatti, A., Brecchia, G., Canali, C., Beckers, J.F., Barile, V.L. (2017). Pregnancy-associated glycoproteins (PAGs) concentrations in water buffaloes (Bubalus bubalis) during gestation and the postpartum period. Theriogenology 97, 73-77.

https://doi.org/10.1016/j.theriogenology.2017.04.021 PMid:28583611

24. Echternkamp, S.E., Vonnahme, K.A., Green, J.A., Ford, S.P. (2006). Increased vascular endothelial growth factor and pregnancy-associated glycoproteins, but not insulin-like growth factor-I, in maternal blood of cows gestating twin fetuses. J Anim Sci. $84,2057-2064$.

https://doi.org/10.2527/jas.2005-714

PMid:16864865
25. Willard, J.M., White, D.R., Wesson, C.A., Stellflug, J., Sasser, R.G. (1995). Detection of fetal twins in sheep using a radioimmunoassay for pregnancy-specific protein B. J Anim Sci. 73(4): 960-966.

https://doi.org/10.2527/1995.734960x PMid:7628973

26. Ledezma-Torres, R.A., Beckers, J.F., Holtz, W. (2006). Assessment of plasma profile of pregnancy-associated glycoprotein (PAG) in sheep with a heterologous (anticaPAG55+59) RIA and its potential for diagnosing pregnancy. Theriogenology 66(4): 906-912. https://doi.org/10.1016/j.theriogenology.2006.02.031 PMid:16566995

27. Shahin, M., Friedrich, M., Gauly, M., Holtz, W. (2014). Pregnancy-associated glycoprotein (PAG) profile of Holstein-Friesian cows as compared to dual-purpose and beef cows. Reprod Domest Anim. 49(4): 618-620. https://doi.org/10.1111/rda.12336 PMid:24888733

28. El Amiri, B., Karen, A., Sulon, J., Melo, de Sousa, N., Alvarez-Oxiley, A.V., Cognie, Y., Szenci, O., Beckers, J.F. (2007). Measurement of ovine pregnancy-associated glycoprotein (PAG) during early pregnancy in Lacaune sheep. Reprod Domest Anim. 42(3): 257-262.

https://doi.org/10.1111/j.1439-0531.2006.00761.x PMid:17506803

29. Rovani, M.T., Cezar, A.S., Rigo, M.L., Gasperin, B.G., Nóbrega Júnior, J.E., Torres, F.D., Gonçalves, P.B., Ferreira, R. (2016). Evaluation of a bovine pregnancy-associated glycoprotein enzyme-linked immunosorbent assay kit for serological diagnosis of pregnancy in sheep. Ciênc Rural. 46(2): 362-367. https://doi.org/10.1590/0103-8478cr20150270

30. El Amiri, B., Remy, B., Sousa, N.M., Joris, B., Ottiers, N.G., Perenyi, Z., Mboko, H.B., Beckers, J.F. (2003). Isolation and partial characterization of three pregnancy-associated glycoproteins from the ewe placenta. Mol Reprod Dev. 64(2): 199-206. https://doi.org/10.1002/mrd.10246 PMid:12506352

31. El Amiri, B., Remy, B., De Sousa, N.M., Beckers, J.F. (2004). Isolation and characterization of eight pregnancy-associated glycoproteins present at high levels in the ovine placenta between day 60 and day 100 of gestation. Reprod Nutr Dev. 44(3): 169-181. https://doi.org/10.1051/rnd:2004025 PMid:15460157

32. Klisch, K., De Sousa, N.M., Beckers, J.F., Leiser, R., Pich, A. (2005). Pregnancy associated glycoprotein $-1,-6,-7$, and-17 are major products of bovine binucleate trophoblast giant cells at midpregnancy. Mol Reprod Dev. 71(4): 453-460.

https://doi.org/10.1002/mrd.20296 PMid:15822115 
33. Xie, S.C., Low, B.G., Nagel, R.J., Kramer, K.K., Anthony, R.V., Zoli, A.P., Beckers, J.F., Roberts, R.M. (1991). Identification of the major pregnancyspecific antigens of cattle and sheep as inactive members of the aspartic proteinase family. Proc Natl Acad Sci USA. 88(22): 10247-10251.

https://doi.org/10.1073/pnas.88.22.10247

PMid:1946444 PMCid:PMC52905

34. Wallace, R.M., Pohler, K.G., Smith, M.F., Green, J.A. (2015). Placental PAGs: gene origins, expression patterns, and use as markers of pregnancy. Reproduction 149(3): R115-126. https://doi.org/10.1530/REP-14-0485

PMid:25661256
35. Haugejorden, G., Waage, S., Dahl, E., Karlberg, K., Beckers, J.F., Ropstad, E. (2006). Pregnancy associated glycoproteins (PAG) in postpartum cows, ewes, goats and their offspring. Theriogenology 66(8): 1976-1984.

https://doi.org/10.1016/j.theriogenology.2006.05.016 PMid:16870244

Please cite this article as: Adeyeye A.A., Abubakar Y.U., Leigh O.O., Ate I.U., Stephen J., Raheem K.A., Ubah S.A. Pregnancy-specific protein B in Yankasa ewes during pregnancy and postpartum periods. Mac Vet Rev 2021; 44 (1): 55-62.

https://doi.org/10.2478/macvetrev-2021-0010 